\title{
The German Organization for Security and Co-operation in Europe (OSCE) Chairmanship in 2016 $^{1}$
}

\author{
Éva REMEK ${ }^{2}$
}

Germany planned its 2016 Chairmanship of the OSCE to establish the following goals "to renew dialogue and to restore trust among participating states and the security of Europe". ${ }^{3}$ [30] Germany supported actual work on the priorities of its Chairmanship, which involved e.g.-inter alia-strengthening OSCE capabilities across the conflict cycle, ${ }^{4}$ handling old and new challenges of the fundamental freedoms in the OSCE region, strengthening good governance, and other new types of challenges. The German Chairmanship continued the work of the earlier chairmanships of previous years. There are state "chairs" (Switzerland and Serbia held the OSCE Chairmanships in 2014 and 2015, they are the OSCE Troika) $)^{5}$ and they started a "new model to address new challenges". ${ }^{6}$ Related to that it should be noted (for this work's keywords), that Foreign Minister Steinmeier said: "Germany wanted to durably strengthen the OSCE and its tradition of an equal dialogue among all participating States. This was the only way to rebuild lost trust and restore security on the European continent in the long term. This was all the truer against the background of the conflict in Ukraine, in which the OSCE had proved its outstanding importance and indispensability." [30]

This analysis aims to present the work done throughout 2016. This paper shows and demonstrates that during the German chairmanship of the Organization a meaningful dialogue was lead and co-operation was pursued in various fields of common interest (mainly their role in context of the European security and the Ukrainian crisis) throughout the dimensions of the OSCE. The OSCE approaches security along these three dimensions: the politico-military, the economic and environmental, and the human.

1 The work was created in commission of the National University of Public Service under the priority project PACSDOP-2.1.2-CCHOP-15-2016-00001 entitled “Public Service Development Establishing Good Governance” in the Miklós Zrínyi Habilitation Program.

2 Ph.D., Associate Professor, National University of Public Service, Faculty of International and European Studies; e-mail: remek.eva@uni-nke.hu

3 ZIF - Center for International Peace Operations: "Renewing Dialogue, Rebuilding Trust, Restoring Security”. [30]

4 “I.e. early warning, conflict prevention, crisis management and post-conflict rehabilitation.” [30]

5 The OSCE Troika was invented at the Helsinki Summit in 1992 to bring an element of continuity to the OSCE's leadership. It is a format of cooperation between the present, previous and succeeding Chairmanships.

6 Germany made a declaration at the end of its presidency (Hamburg Declaration see later in the text) and the OSCE Troika invited the all participating States commonly to work "along five lines of action”. I believe its earlier goal has been achieved with this document. Hamburg Declaration. Source: http://osce.org/ cio/287946?download=true (Downloaded: 20.04.2017) 
É. REMEK: The German Organization for Security and Co-operation in Europe...

This study is a part of my research work, so in the current text details also can be read with reference to the earlier and subsequent studies, which have already been or will have been written. This seems inevitable because, as I have pointed out above, my previous and next studies have referred/will refer to OSCE, crisis management and Ukrainian events, too.

Keywords: OSCE, German Chairmanship, crisis, security, dialogue, trust

\section{Introduction}

Germany took over the Chairmanship of the OSCE on 1 January 2016. This was the second time when Germany had guided the world's largest regional (pan-European) security organization [31] since 1991. Foreign Minister Frank-Waltzer Steinmeier was the organization's Chairperson-in-Office, while Gernot Erler was the Federal Government’s Special Representative for Germany's OSCE Chairmanship in 2016. [30]

Given the title of the analysis, obviously the question is raised: what did the OSCE Chairmanship mean for Germany? "Taking on the OSCE Chairmanship was a major project," said Frank-Walter Steinmeier,7 "involving over 300 events in Vienna, Berlin, Potsdam, the entire OSCE area, and last but not least the grand finale in Hamburg, the Ministerial Council in December 2016”. [1] From a political point of view, the Minister said, Germany had sent a clear message in the light of the tasks that they "believe in effective multilateral organizations, especially now in these times of turbulence, upheaval in the international order and, all over the world, the resurgence of nationalism..." [1] and they are "willing to actively take on responsibility in such situations”. [1]

It is known that the Organization for Security and Cooperation in Europe is the most comprehensive regional security organization, comprising 57 participating states from Europe, Eurasia and the Euro-Atlantic region. ${ }^{8}$

It should be mentioned that in 1975 thirty-five countries established a "cooperation forum". Namely this was the Conference on Security and Cooperation in Europe (CSCE) which was a real forum for dialogue and consultation from Vancouver to Vladivostok. This organization was founded with these goals: "to ensure peace, stability and democracy for more than a billion people”. [2: 24] The Conference on Security and Cooperation in Europe was the predecessor institution of the OSCE, which concluded with the signing of the Helsinki Final Act. During the Cold War, the organization served as an important multilateral forum for dialogue and negotiation between East and West. The CSCE was officially renamed OSCE on 1 January 1995..$^{9}$ [4]

Today the situation is similar to the then time, i.e. the OSCE is continuing to provide its participating states with effective, efficient tools and deals with current security issues. Although the OSCE lacks NATO’s military capabilities and the European Union’s (EU)

Former OSCE Chairperson-in-Office, Germany, 2016. At the end of Germany’s OSCE Chairmanship in 2016, Foreign Minister Steinmeier took a very personal look back over the year and the next quotes came from there.

8 The OSCE is the only security-policy organization in which all European countries and Russia, the USA, Canada etc., and Mongolia are represented. Mongolia became the 57th participating State on 20 November, 2012. [32]

9 Budapest Summit marked the change from CSCE to OSCE in 1994. Among other things it is important that ministers formally "have adopted” the Code of Conduct on politico-military aspects of security. [3: 3] 
economic resources, yet no other security organization has a mandate to act in such a large geographical area. This makes OSCE the key player in conflict prevention and resolution, crisis management and hence its uniqueness among internaional players. Quoting NATO Secretary General Jens Stoltenberg: “...the efforts of Germany’s OSCE Chairmanship to focus on renewing dialogue and strengthening the OSCE's instruments and discussion forums...”, [5] the OSCE is a "key player in many areas of particular interest to the Alliance." [5]

\section{The Changing Face of European Security}

"In early 2014, nobody even assumed that only a few months later European security would be significantly compromised." [2: 26] It is not possible to formulate the essence better than the CNN's riporter did it. "It began as a dispute over a trade agreement, but it mushroomed into the bloodiest conflict in Europe since the wars over the former Yugoslavia in the early 1990s.” [25]

In Ukraine people were dissatisfied with President Yanukovych and no longer supported him. There was a growing and growing disaffection with the government. This situation eventually resulted in a demonstration, after violent and powerful anti-government demonstrations, at the end it became military clash. It was the worst crisis not only for European security but also for global security. Germany took over the OSCE Chairmanship at a difficult moment in European security. The experts said ${ }^{10}$ that "illusions of quick fixes to the deep strategic confrontation between Russia and the West should be avoided, but opportunities for practical confidence-building standards need to be kept”. [17: 1]

This situation has seriously affected Europe. “The world will never be the same again”, said European Council President Herman van Rompuy after, when the Crimea was captured. [26]

It was under these circumstances that the Chairperson-in-Office, Swiss Foreign Minister and President of the Confederation"11 launched the "Panel of Eminent Persons on European Security as a Common Project” (hereinafter called Panel) at the Ministerial Council in Basel in 2014. The idea was to make ready for use on the basis for full range security dialogue across the Euro-Atlantic and Eurasian regions, focusing on consideration the Ukraine crisis and especially the importance of security in the OSCE area. [7]

The Panel's main task was to work out how to rebuild trust and reconsolidate European security on the basis of the Helsinki Final Act and the Charter of Paris and on how to support the principles of OSCE. Therefore, the task is examining what kind of threats in the OSCE area and researching common responses to confirm again cooperative security. It is important to emphasize that the Summary of the Panel's task outlines the particular role of the OSCE in Euro-Atlantic and Eurasian security. Its role is unchanged, namely the old-new task is preventing and resolving crises (that is also the case in Ukraine). The importance of this task can be measured in the long term. And fact it will have a strong effect on the German chairmanship work. Why? Because general guidance for the Panel's work was given by the OSCE Troika, composed of the outgoing Swiss (2014), (the then 2015) Serbian and incoming German Chairmanship (2016). The Panel is attempting to find input from the OSCE participating States, the OSCE Secretariat, other Institutions and Parliamentary

\footnotetext{
10 Dr. Petri Hakkarainen is a Senior Diplomatic Advisor at the Geneva Center for Security Policy (GCSP) and Dr. Christian Nünlist is a Senior Researcher at the Center for Security Studies (CSS) at ETH Zürich.

11 Didier Burkhalter.
} 
Assembly, multilateral organizations concerned with European security issues, civil society and think tanks, etc. ${ }^{12}$ [10: 20] As we see nowadays, this idea was an extremely good one for two reasons. On the one hand none of the existing international organizations, groups or institutional agreements have been able to find a peaceful settlement to the conflict over eastern Ukraine, including the Crimea situation. It means that it focuses on arms contorol, reduction armaments, or just questions of trust in political relations. On the other hand, I think that it is time, when the OSCE is able to realize its own comparative preferences, values i.e. its inclusive nature and consensus-based decision making. As we know the OSCE has been the most relevant framework to manage the Ukraine crisis (at present there are three missions). ${ }^{13}$ [8: 23-27]

The aims of the organization's management were "to continue to play a useful role, the body must adjust its methods and strengthen its toolbox". [9] What does it mean? This is a new opportunity for OSCE reform. As I have already mentioned above, the Panel's task was preparing proposals to resolve the Ukrainian crisis. In June 2015, this Panel delivered two documents: [10: 2] an Interim report on the Lessons learned from the Ukraine crisis. ${ }^{14}$ And the Final report on the broader issues of security in Europe and in the OSCE area was to be presented toward the end of $2015 .^{15}$ [11] From these documents we can clearly read that the OSCE has become relevant again. "The reason for this is not because the West and Russia have overcome their differences, but because their relations declined to a point at which both sides needed to turn to the organization's crisis management tools to contain the risks of a dangerous escalation.” [9: 13]

In this process the Troika is a significant player (in our case Serbian, German and Austrian chairmanship), through this process the organization will continue to stabilize the situation.

It appears that, the OSCE's role may even increase further. Of course, it depends on many factors (participating States' interest, economic situation, effect of sanctions against Russia, etc.). However, as long as this acute challenge dominates the agenda, there will be little chance for serious efforts on the longer-term reform of the organization. According to the experts' view the Panel's “initial paper on the lessons learned from OSCE crisis management in Ukraine was useful”. [9: 14]

Furthermore, it is important to realise that given the current polarization among member states, the Panel is "unlikely to achieve agreed conclusions on the future perspectives of the organization". [9: 14] At best, it will present an interesting variety of options and diverse viewpoints. “Germany’s assumption of the OSCE chair in January 2016 was potentially more

12 It is mportant to quote the words of Fred Tanner. (He is Ambassador, a Senior Adviser in the Office of the OSCE Secretary General. He is the OSCE Secretariat Project Manager of the Panel of Eminent Persons on European Security as a Common Project): “The Panel and individual members also make use of opportunities to engage with high-level representatives of participating States (for example inside events at multilateral conferences and other international events). The Panel is assisted by a support unit that provides operational and logistical assistance in convening meetings as well as substantive support in drafting the reports.

The OSCE Network of Think Tanks and Academic Institutions is contributing research and position papers. The Panel is financed through voluntary contributions.” [7]

13 All OSCE operations are described by the next aspects: basic decision, tasks, deployment, duration, composition, fianancial implications.

14 This document focused mainly on operational issues.

15 "As soon as the Minsk commitments are in place on the ground, the Panel recommends that the OSCE Chairmanship, supported by the OSCE Troika, and in communication with the Ukraine Contact Group, launch a diplomatic process to rebuild the foundation of European security.” [11: 13] 
promising. For one, it brought the political level of crisis management on Ukraine, in which Berlin has been a leading actor, closer to the operational dimension handled by the OSCE. This could allow the OSCE to have a stronger political role and at the same time strengthen the effectiveness of the organization's operational action.” [9: 14]

Thus, the German Chairmanship in 2016 was very operative, because Germany would be suitable to give a fresh power and dynamism to the work of the organization. As a leading EU member state with "strong relations with Washington and Moscow, Berlin has a better chance than any other capital to break through the existing stalemate and help the OSCE find a new sense of direction and purpose”. [9: 14]

We consider this organization as a comprehensive and inclusive forum, as a platform for real dialogue between the two confrontational sides, but its capacity to influence the quality of their relations in the different task is limited. But the really important decisions are made within national framework or highlighted in the organizations (e.g. UN, NATO, the EU, Council of Europe, etc.). I would like to quote Pierre-Emmanuel Thomann about the EU and Russia that "they need also to identify common geopolitical interests in order to engage in a strategic dialogue. They could address three pivotal thematics at global, pan-European and regional levels: the continental axis, the missing link of European security and the common neighbourhood”. [12]

We must acknowledge that the geopolitical environment is changing. After Brexit and its consequences, the EU should focus more on the real events. For example, although the European Union targets strategic autonomy, "strategic autonomy must be achieved over time”, [13: 16] but strategic autonomy does not mean that one does not need partners, particularly NATO. The specifics of each crisis at hand will make clear the appropriate actor (the EU, the UN, NATO, country, ad hoc coalition, etc.) to take the lead in crisis management. [13: 16-17] This is well and authentically illustrated in the figure below. (Figure 1) This conception is built on the international organizations in which the OSCE definitely gets a role. Behold a not-well-known opinion, but the question (some kind of lack of European security) is worthy of further consideration. (Figure 1)

\section{Fragmentation of the European and Eurasian Security Order}

It can be treated as a fact that the challenges in front of the world are numerous and complex, that is why it is difficult to resolve them. The situation in the OSCE area is characterized by a number of major "fragmentation zones" as well as security challenges. These can be classified into four groups: first, fragmentation and divisions within and between societies; second, fragmentation within the integration structures; third, conflicts in Russian-Western relations; fourth, negative influences from the outside. [20: 11] (Here, only the second and third group will be presented.)

\section{The second group: fragmentation within the integration structures}

The EU is a most special entity, modern integration structure in the OSCE area (all EU member states are at the same time participating States of the OSCE). "Its development is key for the whole of Europe, and the EU-Russia relationship is a major pillar of the European security 
system." 16 [20] "NATO is also facing significant challenges in relation to the conflict for example in Syria, where different member states are going on different and even conflicting strategies." ${ }^{17}$ [20] Moreover, the current situation is difficult, therefore it is difficult to resolve burden sharing proportionally among stakeholders. An interesting example is the Eurasian Economic Union (EEU) that has not yet become a driver of economic cooperation among its member states (the Ukraine crisis has caused political problems among members), ${ }^{18}$ but their national interests' realization depends on the relationship between Russia and the West. The situation is similar to the Collective Security Treaty Organization, too. The solution has been found by these countries through their multidirectional foreign and security policies. ${ }^{19}$

\section{Third Group: conflict in Russian-Western relations}

According to the experts' opinion Russia's involvement in the Ukraine crisis was worrying in the West, especially among Russia's neighbours. That is to say after the Cold War, the Moscow's policy purpose was the review of the European security architecture. This was a revisionist idea. At least this has moved Russia's neighbours, which have already become members of the EU and NATO, "to seek credible reassurances from the Alliance and to move towards a deterrence posture vis-a-vis Russia”. [20: 14] The expert writings really indicate perceptible, some times a "Cold War behavior", and it is determined that "this kind of essentialist approach is a really alarming sign”. ${ }^{20}[20]$

How does all this relate to the German OSCE Chairmanship? So, this crisis or conflict is now more dangerous, with "no clear rules of the road". ${ }^{21}$ [33] The German foreign minister, Frank-Walter Steinmeier, an advocate of dialogue made the same (see before) point: "It's a fallacy to think that this is like the Cold War. The current times are different and more dangerous." [33]

\section{The Missing Link of the European Security}

Another reading of the fragmentation problem examines the issue of European security as a whole. What do these "Olympic circles” mean? The interesting approach draws attention to the lack of "European security link”. (Figure 1)

\footnotetext{
16 More details of the EU's internal disagreements, the deep socioeconomic North-South, Brexit and etc. are in [20: 11-13].

17 Ibid.

18 More details see in [20:12].

19 It means that they strive for enlargement their relations with NATO, the EU, the OSCE to balance their relationship with Russia.

20 By working group [20:14].

21 Sir John Sawers, the former head of MI6 said. [33]
} 


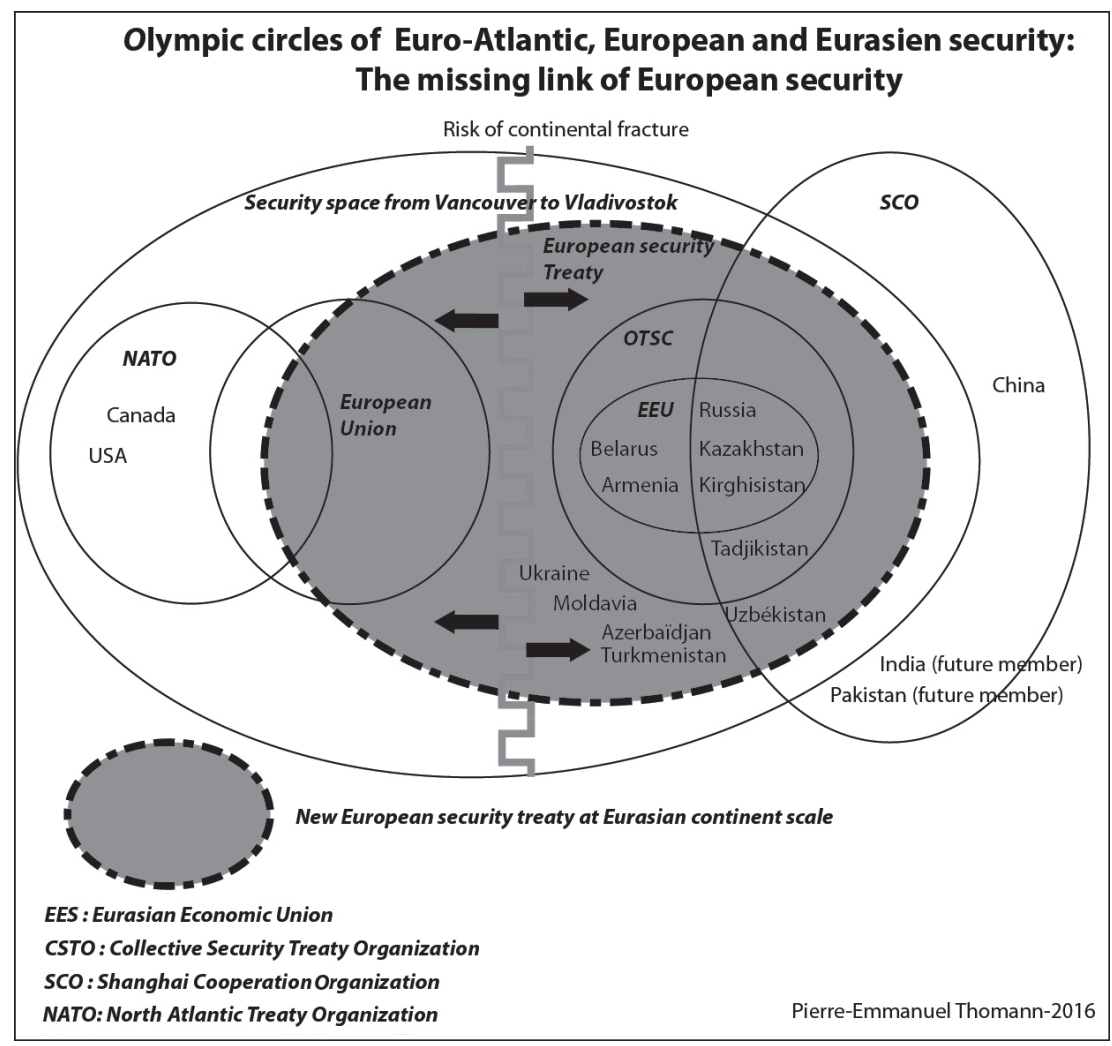

EEU: Eurasian Economic Union

OTSC: Organisation du Traité de sécurité collective, namely Collective Security Treaty Organization (CSTO) SCO: Shanghai Cooperation Organization NATO: North Atlantic Treaty Organization

Figure 1. "Olympic circles" of Euro-Atlantic, European and Eurasian security to fix the missing link of European security. [12]

According to the experts again, ${ }^{22}$ it would be therefore interesting to imagine new treaties and institutions, resembling the "olympic circles" ${ }^{23}$ which would allow maintaining stability on the whole Eurasian continent. There is a common interest. However the missing European security can be restored on an equal and rule-based economic cooperation with the EU-Russia. [12] We must understand that the OSCE is important, but specific institutional arrangements might be necessary.

22 Pierre-Emmanule THOMANN is Scientific Advisor in geopolitics and geostrategy at the European Institute for International Relations (IERI), Brussels.

23 "Olympic circle": A new "security space" from Lisbon to Vladivostok would be the inner circle of the security space from Vancouver to Vladivostok. In this configuration, we would find the EU as a pivot/political centre and Russia as a neighbouring pivot/political centre at the crossroad of overlapping security spaces from Vancouver to Vladivostok (NATO and OSCE, USA-EU-Russia), Lisbon to Vladivostok (EU-Russia), St. Petersburg to Peking (OCS) and Minsk-Duchanbe (OTSC). [12] 
The expert's opinion says that there is a missing link in the European security architecture that needs to be fixed in order to avoid a further fragmentation of the European continent between Euro-Atlantic and Euro-Asian alliances. We also have to assume that an enlargement of Euro-Atlantic institutions (NATO-EU-OSCE) to the whole of the Eurasian continent is impossible. Why? Thomann argues that firstly, further enlargement is not on the EU's and NATO's agenda. Secondly, the Euro-Atlantic institutions are unable to handle the geopolitical diversity of the Eurasian continent. "The solution to fixing the missing link in the European security architecture is based on the "geographical tightening" principle in the context of NATO’s and EU's overstretched capacities. Geographical proximity would be a central criterion to build regional alliances in order to foster stability and prevent further Eurasian fragmentation.” [12]

The only question is how would it be possible to balance among the different states, the alliances and the political and security institutions in the area of the continental fracture? The answer is evident, that is the balancing can be solved using the OCSE dialogue and co-operation methods. ${ }^{24}$

\section{The Five Priority Areas}

"The German Chairmanship in 2016 was an interesting diplomatic experiment for the OSCE”, [14] because a real political "heavyweight” was taking over the Chairmanship. "Germany is the most powerful OSCE participating state ever at the helm of the organization in its 20-year history.” [14]

Under the motto "Renewing Dialogue, Rebuilding Trust, Restoring Security", the German Osce Chairmanship 2016 planned five priorities. The most important priority was the Ukrainian situation, namely focused on crisis and conflict management in and around Ukraine. Furthermore, “Germany will also continue the OSCE's long standing work on finding lasting solutions to the so-called protracted conflicts in the OSCE area, including Transdniestria, Nagorno-Karabakh and the South Caucasus.” [15] Secondly, they have to strengthen the OSCE's capabilities at all levels the conflict cycle, but this idea affects the increase of the budget, too. Thirdly, the OSCE has a major task in the area of the arms control and the renewal of the Vienna Document ${ }^{25}$ on Confidence and Security-Building Measures. This proposal is promoted by such seminar works as High-Level Military Doctrine Seminar which Berlin focused on (it has also been realized). Fourthly, the issue of the human dimension was highlighted. Germany payed special attention to this area, because it is related to current crises and security problems such as tolerance and non-discrimination, freedom of expression, freedom of the media, and minority rights, etc. "The human dimension is an area of considerable disagreement among OSCE participating States with Russia and some of its proxies accusing the West of double standards and distorting the balance between the three security dimensions of the OSCE.” [15] Finally, the economic (and environmental) dimension was on the meeting table. This would be a good opportunity to make better and more effective this dimension when there are no progresses in the other two (politico-military, human) dimensions. The Presidency focused on two issues inside this dimension: good governance and connectivities (dialogue between the public and the private sector). This 
dimension really received great attention during the German presidency, so much so that e.g "Good Governance was the main theme in 2016 year's Economic and Environmental Forum, [...] good governance was a key topic at the Economic and Environmental Dimension Implementation Meeting..."26 [16: 9]

After these the expert's question is straightforward and legitimate: “Germany a neutral and honest broker?”27 [15] Germany’s priorities were generally welcomed and supported by most of the OSCE participating States. The real question is how did Berlin manage the renewed confrontation between Russia and the West? It seems that a common understanding was missing (the European security system is fractured, see above) therefore the finding an acceptable solution was waiting for the German Presidency. ${ }^{28}$ In addition, the Final Report ${ }^{29}$ [35] is proof that "the role the OSCE could play today in the form of a common forum for mediation and conflict prevention is more important than ever, as military tension and the likelihood of accidents and conflict escalation is increasing”. [20: 8]

According to Stephanie Liechteinstein ${ }^{30}$ "with regard to the Ukraine crisis, Germany will be expected to act as honest and neutral broker and to help build consensus.” But neutral by all sides? In her view Germany is "the leading power within the EU and a strong member of NATO”. All the two previous Chairs, Switzerland and Serbia were neither EU nor NATO members. Switzerland was "well-placed to mediate between Russia, the West and Ukraine”, still it is neutral. Hence, Germany may be "viewed as lacking neutrality, especially when it comes to mediating between the parties" to the Ukraine crisis. Namely, Germany has supported sanctions against Russia within the EU and is a member of NATO. "Thus, for Berlin, its engagement with Moscow has so far been dominated and influenced by the former's role in those two Western institutions." 31 [15]

The OSCE Chairmanship was a great opportunity for Berlin in connection with Moscow. First of all Germany was in the same organization in which Russia was an equal partner. Moreover, it was an organization where decisions were taken by consensus. "Germany can thus deal with Moscow in a more balanced way, not overshadowed by EU sanctions or military rhetoric. This may open new possibilities to ease tensions, which today can neither be managed through the EU nor through NATO.” [15] Secondly, the changes within the EU and NATO have affected the Euroatlantic region. Germany was/is a powerful state within the two organizations. It was especially important that it could keep the opportunity of its OSCE Chairmanship in order to maintain a balance between parties (the EU, NATO and Russia)..$^{32}$ [17: 2]

"The priority status of the Ukrainian conflict and talks with Moscow has been shown by the appointment of Gernot Erler (SPD) as Special Federal Representative in the OSCE. Gernot Erler was a close associate of Minister Steinmeier between 2005 and 2009. He has served as Secretary of State in the Foreign Affairs Ministry in charge of Germany's Eastern

26 All details on the Report [16: 9-10]

27 Stephanie Liechtenstein's question.

28 It should be mentioned the Final Report of the Panel of Eminent Persons (details see above) could be useful in this context. For this to happen it is all-important that the dialogue on European security issues should continue permanently within the OSCE.

29 As recommended by the OSCE Network of Think Tank and Academic Institutions. [35]

30 This paraghrap is based on her complete study [15].

31 It is important to mention that German Chancellor Angela Merkel has always had a privileged relationship with Russian President Vladimir Putin.

32 More details of the difficulties in paragraph: Defusing Conflicts Outside the Vienna Agenda. [17: 2] 
policy and, since January 2014, as Federal Coordinator for Russia, Central Asia and Eastern Partnership." [28: 2-3] The negotiating framework was "a perfect distraction from the multilateral diplomacy of NATO member states towards Russia, which is critical due to the suspended cooperation between the NATO Council and Russia”. [28: 3]

Although the Ukrainian conflict remained the most important task, the German presidency continued to give political support to other observation missions, and cooperation with 55 experts. [17: 3] They pad particular attention to Transdniestria, South Caucasus and Nagorno Karabakh. The Berlin presidency considered important the member states' contribution to the OSCE budget, itself being the second largest contributor. The OSCE budget was $€ 141.1$ million in 2016. [28: 3]

How could the German presidency accomplish tasks of the five priorities area? What methods and tools were used? We could keep asking questions endlessly, but there are also answers.

It was not easy, but Germany was able to make good use of its own potential. "Whether the format includes ministers, senior officials from capitals, or ambassadors in Vienna, informal high-level meetings should be encouraged as much and as often as possible to continue a confidential dialogue aiming at bridging the gap.” [17: 3] Furthermore, Germany could also use its OSCE Chairmanship to make easy Track One and Half ${ }^{33}$ or Track Two Diplomacy ${ }^{34}$ "in carefully chosen fields, harnessing the capacity of think-tanks and research institutions for a common cause". [17: 3] So, the "keeping lines of communication" were open, the Chairmanship focused on small, concrete steps to begin improving the confrontational atmosphere and to create mutual trust. Five areas $^{35}$ seem particularly well-suited to create these “cooperative islands”. [17: 2]

The following quotation is useful for a summary "The Ukraine conflict has therefore contributed to a 'German moment' without (as yet) transforming it into a European moment”. [22: 112] German Presidency played pronounced role in crisis management in Ukraine and in the realization of negotiations between the Ukrainian and Russian parties. E.g. Steinmeier Foreign Minister presented the OSCE Observer Mission in 2014 and together with the Swiss OSCE Chairmanship made efforts to set up a special observation mission. Furthermore, Germany was closely concerned "in the shuttle diplomacy of the Swiss OSCE chairship for the establishment of a trilateral contact group at the beginning of June 2014 under Swiss Ambassador Heidi Tagliavini, which led to the conclusion of the first Minsk agreement on September 5, 2014 between Moscow, Kiev and pro-Russian separatists.” [22: 125-126] This preference for the OSCE is also related to the OSCE tools (dialogue, cooperation, presence diplomacy), when the Swiss OSCE chairship was, which immediately offered OSCE support for crisis management. So in the end "as a result, the OSCE gained importance as an institution for crisis management and emerged from the conflict reinforced, while the EU has been weakened." [22: 126]

It seems to me this example demonstrates that the OSCE can be a relevant partner for the current Presidency, and this was proven during the German Presidency, too.

\footnotetext{
33 Track One and a Half Diplomacy as "unofficial interactions between official representatives of states".

34 Track Two Diplomacy offers insights into the role of informal and non-official discussions in resolving conflicts. Informal diplomacy is a relatively new one in the field of international relations.

35 For details of areas see in [17: 3].
} 
É. REMEK: The German Organization for Security and Co-operation in Europe...

\section{Conclusion}

Jean Monnet was right, who was often called the founding father of the European Union, when he said: "Without men nothing is possible, without institutions nothing is permanent." [6] Later Jaakko Iloniemi [6] also pointed out the same thing about the OSCE. Quoting him in his own words "political and legal institutions that are strong enough to weather storms and upheavals are the best guarantee we have for an orderly and successful management of international relations". [20: 9] It can be stated that the OSCE can fulfil its roles and mandates.

The German Foreign Minister himself thus appreciated the annual work: "Without a doubt, the path there is a very, very long one. But let me borrow a quote from Willy Brandt: Small steps, he said, are better than no steps. Willy Brandt was himself a trailblazer for the CSCE. He would advise to take the small steps now, while the large steps are still far off."36 [36] And the German Foreign Minister said as OSCE Chairmanship in his closing remarks, left the participating States with a question: "A quarter of a century after the end of the Cold War, we find ourselves at something like a crossroads. We are faced with the fundamental question: do we want to continue pursuing this vision of cooperative and comprehensive security or not?"37 [21: 4]

A remarkable statement by the foreign ministers of Germany, Italy and Austria to strengthen the role of the Organization for Security and Cooperation in Europe has been read on the pages of the Frankfurter Allgemeine Zeitung. "Just in stormy times, we need a strong OSCE”, said with one voice Frank-Walter Steinmeier, Paolo Gentiloni ${ }^{38}$ and Sebastian Kurz. The three ministers identified some common areas for action, such as "the creation of new platforms for dialogue and for a lasting solution of the crisis in Europe, a new beginning of monitoring conventional arms, a common approach to global challenges. The ministers speak of "too restless times in Europe" that "have questioned the architectural pillars of European peace” and they again mentioned the Ukrainian crisis. [23]

To sum up the German OSCE's method (cooperation, dialogue, presence diplomacy, trust) which at the same time is an effective instrument not only in the Ukrainian crisis, but it also would be a good example for crisis management elsewhere. And as Swiss Foreign Minister Didier Burkhalter once said: "The OSCE has become the eyes and the ears of the international community in Ukraine.” [29: 2]

\section{References}

[1] Foreign Minister Frank-Walter Steinmeier on the End of Germany's OSCE Chairmanship 2016. Berlin: Federal Foreign Office, 2016. www.auswaertiges-amt.de/en/aussenpolitik/ internationale-organisationen/osze-5-fragen-bm/286744 (Downloaded: 16.04.2017)

The full speech can be read at [36].

Ministerial Council, Hamburg, 2016.

The OSCE stretches "from Vancouver to Vladivostok (and its) concept of security is now more relevant than ever,” said Italian Foreign Minister Paolo Gentiloni. [24] 
É. REMEK: The German Organization for Security and Co-operation in Europe...

[2] OBRADOVIĆ, A.: OSCE and Contemporary Security Challenges. The OSCE and Contemporary Security Challenges: A Collection of Essays. www.osce.org/ serbia/216966?download=true (Downloaded: 16.04.2017)

[3] Code of Conduct on Politico-Military Aspects of Security. Vienna: OSCE, 1994. www.osce. org/fsc/41355?download=true (Downloaded: 16.04.2017)

[4] Budapest Documentum, 1994. Budapest Summit Declaration, towards a Genuine Partnership in a New Era. Budapest: CSCE, 1994. www.osce.org/mc/39554?download=true (Downloaded: 16.04.2017)

[5] NATO and OSCE Discuss Modernising Tools of Military Transparency. http://nato.int/cps/ en/natohq/news_127481.htm?selectedLocale=en (Downloaded: 16.04.2017)

[6] ILONIEMI, J.: Not just another Tea Party. The Lasting Value of the OSCE. Finnish Foreign Policy Papers, 0412 (2015). www.css.ethz.ch/content/dam/ethz/special-interest/gess/cis/ center-for-securities-studies/pdfs/PP4-1.pdf (Downloaded: 19.04.2017)

[7] TANNER, F.: Rethinking the OSCE and Security in Europe. The OSCE Magazine, 1 (2015). www.osce.org/magazine/171266 (Downloaded: 17.04.2017)

[8] Survey of OSCE Field Operations, SEC.GAL/27/16, 18 February 2016. www.osce.org/ cpc/74783?download=true (Downloaded: 17.04.2017)

[9] LEHNE, S.: Reviving the OSCE: European Security and the Ukraine Crisis. Carnegie Europe Paper, 22 September 2015. http://carnegieeurope.eu/2015/09/22/reviving-osceeuropean-security-and-ukraine-crisis-pub-61362 (Downloaded: 17.04.2017)

[10] Lessons Learned for the OSCE from its Engagement in Ukraine. Interim Report and Recommendations of the Panel of Eminent Persons on European Security as a Common Project. www.osce.org/networks/164561?download=true (Downloaded: 17.04.2017)

[11] Back to Diplomacy. Final Report and Recommendations of the Panel of Eminent Persons on European Security as a Common Project. www.osce.org/networks/205846?download=true (Downloaded: 17.04.2017)

[12] THOMANN, P. E.: The European Project and Russia: The Necessity to Identify Common Geopolitical Interests to Overcome the Current Crisis. Eurocontinen, Publié, 1404 (2017). www.eurocontinent.eu/\#_edn1 (Downloaded: 17.04.2017)

[13] After the EU Global Strategy—Consulting the Experts, Security and Defence. Paris: European Union Institute for Security Studies, 2016. www.egmontinstitute.be/wp-content/ uploads/2016/10/After_Global_Strategy_online_.pdf (Downloaded: 17.04.2017)

[14] NÜNLIST, C.: Successful Small States in the OSCE and the German Chairmanship of 2016. (Only the abstract is available.) www.researchgate.net/publication/289600984_Successful_ Small_States_in_the_OSCE_and_the_German_Chairmanship_of_2016 (Downloaded: 20.10.2017) DOI: https://doi.org/10.1163/18750230-02601002

[15] LIECHTENSTEIN, S.: Germany Takes over OSCE Chairmanship “Stormy Times”-says Frank-Walter Steinmeier. Security and Human Rights, 2001 (2016). www.shrblog.org/ shr_monitor/Germany_takes_over_OSCE_Chairmanship_in stormy_times says_ Frank_Walter_Steinmeier.html?id=592 (Downloaded: 17.04.2017)

[16] OSCE Deutschland 2016. Report by the 2016 German OSCE Chairmanship. Introduction. www.wien-osze.diplo.de/contentblob/4981634/Daten/7298742/170201_Arbeitsbericht_ Vorsitz.pdf (Downloaded: 20.04.2017) 
É. REMEK: The German Organization for Security and Co-operation in Europe...

[17] HAKKARAINEN, P., NÜNLIST, C.: Trust and Realpolitik: The OSCE in 2016. Policy Perspectives, 41 (2016). http://css.ethz.ch/content/dam/ethz/special-interest/gess/cis/centerfor-securities-studies/pdfs/PP4-1.pdf (Downloaded: 21.10.2017)

[18] MAPENDERE, J.: Track One and a Half Diplomacy and the Complementarity of Tracks. (Conflict resolution.) COPOJ_Culture of Peace Online Journal, 21 (2016), 66-81. http:// peacemaker.un.org/sites/peacemaker.un.org/files/TrackOneandaHalfDiplomacy_Mapendere. pdf (Downloaded: 19.04.2017)

[19] REMEK É.: The Austrian OSCE Chairmanship Programme Focus on the European Security. Vojenské Reflexie, XII 1 (2017). www.aos.sk/casopisy/reflexie/vojenske_reflexieXII_1.pdf (Downloaded: 23.08.2017)

[20] ZELLNER, W., CHERNYKH, I., DÉLÉTROZ, A., EVERS, F., KUNZ, B., NÜNLIST, C., REMLER, P., SEMENIY, O., ZAGORSK, A.: European Security-Challenges at the Societal Level. OSCE Network of Think Tanks and Academic Institutions. http:// osce-network.net/file-OSCE-Network/documents/European_Security-OSCE_WEB.pdf (Downloaded: 20.04.2017)

[21] Security Community. The OSCE Magazine, 4 (2016). www.osce.org/ magazine/292926?download=true (Downloaded: 20.04.2017)

[22] HELVIG, N. (ed.): Europe's New Political Engine. Germany's Role in the EU's Foreign and Security Policy. Helsinki: Finnish Institute of International Affairs, 2016. www.fiia.fi/assets/ publications/FIIAReport44_Europes_New_Political_Engine.pdf (Downloaded: 20.04.2017)

[23] Germany Italy and Austria Call for Stronger OSCE. Foreign Ministers, Faz Reports, Joint Action must be Strengthened. https://anssa.it/nuova_europa/en/news/countries/ germany/2016/12/07/germany-italy-and-austria-call-for-stronger-osce_4bf4063e-7ec6-4208b87a-c4494e17de49.html (Downloaded: 27.04.2017)

[24] Italy Elected OSCE President in 2018. Unanimous Vote by 57 Member Countries. http:// ansa.it/english/news/politics/2016/07/28/italy-elected-osce-president-in-2018_ca0a092c2a17-4d86-9f96-39d312746561.html (Downloaded: 23.04.2017)

[25] THOMPSON, N.: Ukraine: Everything you need to know about how we got here. The country vacillates between getting closer to EU. CNN (online), 1002 2015. http://edition. cnn.com/2015/02/10/europe/ukraine-war-how-we-got-here/index.html (Downloaded: 20.10.2017)

[26] BURAS, P., DWORKIN, A., GODEMENT, F., LEVY, D., LEONARD, M., LIIK, K.: Ten Global Consequences of the Ukraine Crisis. www.ecfr.eu/article/commentary_ten_global_ consequences_of_ukraine272 (Downloaded: 20.10.2017)

[27] ELNER, G.: Key Issues of the German OSCE Chairmanship 2016. Security and Human Rights, 26 (2015) 3-10. www.shrblog.org/shr_special_issue_german_osce_ chairmanship_2016/ (Downloaded: 17.04.2017) DOI: https://doi.org/10.1163/18750230-02601006

[28] SZUBART, K.: The Priorities of the German OSCE Chairmanship in 2016. Bulletin of the Institute for Western Affairs, 221 (2016). http://iz.poznan.pl/en/ file,download,331,22137463fa5273d9b87f494d18795fe8/1375221GermanyOSCE.pdf (Downloaded: 20.10.2017)

[29] GÜNTHER, M.: The OSCE's Importance for Peace and Security in Europe. https:// nefia.org/sites/default/files/zeitschrift/artikel/adhoc_15_EN_17_Guenther_NEU.pdf (Downloaded: 20.10.2017) 
É. REMEK: The German Organization for Security and Co-operation in Europe...

[30] Germany takes over OSCE Chairmanship. Germany sets itself ambitious goals for its Chairmanship of the Organization for Security and Co-operation in Europe (OSCE). deutschland (online), 13. 01. 2016. http://deutschland.de/en/topic/politics/developmentdialogue/germany-takes-over-osce-chairmanship (Downloaded: 20.04.2017)

[31] NÜNLIST, C.: The OSCE and the Future of European Security (first paragraph). CSS Analyses in Security Policy, 202 (2017). http://css.ethz.ch/content/dam/ethz/specialinterest/gess/cis/center-for-securities-studies/pdfs/CSSAnalyse202-EN.pdf (Downloaded: 20.10.2017)

[32] Participating States. osce.org, s.d. http://osce.org/participating-states (Downloaded: 20.04.2017)

[33] WINTOUR, P., HARDING, L., BORGER, J.: Cold war 2.0: How Russia and the West Reheated a Historic Struggle. The Guardian (online), 24. 10. 2016. https://theguardian. com/world/2016/oct/24/cold-war-20-how-russia-and-the-west-reheated-a-historic-struggle (Downloaded: 20.04.2017.)

[34] Vienna Document 2011. On Confidence- and Security- uilding Measures. Vienna: OSCE, 2011. https://osce.org/fsc/86597?download=true (Downloaded: 17.04.2017)

[35] TIILIKAINEN, T. (ed.) Reviving Co-operative Security in Europe through the OSCE. Contribution of the OSCE Network of Think Tanks and Academic Institutions to the Panel of Eminent Persons. Vienna: OSCE, 2015. http://osce.org/networks/188176?download=true (Downloaded: 20.04.2017)

[36] Speech by Foreign Minister Frank-Walter Steinmeier at the OSCE Permanent Council in Vienna. www.auswaertiges-amt.de/en/Newsroom/150702-bm-osze/273072 (Downloaded: 20.04.2017) 